\title{
Holocene oceanographic and climatic variability of the Vega Drift deduced through foraminiferal interpretation
}

\author{
Phillip Szymcek, ${ }^{1}$ Scott E. Ishman, ${ }^{2}$ Eugene W. Domack, ${ }^{3}$ Amy Leventer ${ }^{4}$ \\ ${ }^{1}$ Department of Geological Sciences, Florida State University, Tallahassee, FL 32306, USA (szymcekp@ornl.gov) \\ ${ }^{2}$ Department of Geology, Southern Illinois University-Carbondale, Carbondale, IL 62901, USA (sishman@geo.siu.edu) \\ ${ }^{3}$ Department of Geology, Hamilton College, Clinton, NY 13323, USA (edomack@hamilton.edu) \\ ${ }^{4}$ Department of Geology, Colgate University, Hamilton, NY 13346, USA (aleventer@mail.colgate.edu)
}

\begin{abstract}
A sediment sequence recovered from the Vega Drift, Antarctica was analyzed for benthic foraminifera to determine Holocene oceanographic and climatic variability of the northern Antarctic Peninsula margin. Core NBP0003-JPC38, collected during cruise 00-03 of the R.V. Nathaniel B. Palmer recovered 20.53 meters of Holocene glacio-marine sediments. Samples were collected every $4 \mathrm{~cm}$ for foraminiferal analyses. The data were analyzed using principal component and cluster analyses. Results of these analyses show significant stratigraphic changes in the benthic foraminiferal record of the Vega Drift.

Three assemblages characterize the core, including the Miliammina arenacea, Textularia wiesneri, and Stainforthia fusiformis assemblages. Most agglutinated forms tend to decrease downcore, and comparisons to modern analogues imply post-depositional disintegration, while calcareous taxa indicate non-corrosive bottom waters. The lower to middle Holocene Vega Drift sediments are characterized by the calcareous S. fusiformis assemblage and glacial plume sediments. This assemblage is characterized by calcareous forms including Globocassidulina biora, G. subglobosa, and Nonionella iridea. The planktic species Neogloboquadrina pachyderma is associated with the S. fusiformis assemblage. The $S$. fusiformis assemblage is faunally similar to assemblages described in fjords of the western Antarctic Peninsula and indicates non-corrosive bottom water. Sediments of the mid to upper Holocene interval are characterized by the $T$. wiesneri and M. arenacea assemblages and indicate the presence of Hyper Saline Shelf Water. These assemblages are similar to modern assemblages directly to the south in the Prince Gustav Channel. The upper Holocene is marked by several small intervals with taxonomic characteristics similar to the $S$. fusiformis assemblage, indicating periodic introduction of non-corrosive bottom water to the Vega Drift.
\end{abstract}

Citation: Szymcek, P., S.E. Ishman, E.W. Domack, and A. Leventer (2007), Holocene Oceanographic and Climatic Variability of the Vega Drift Revealed Through Foraminiferal Interpretation - Online Proceedings of the $10^{\text {th }}$ ISAEC, edited by A.K. Cooper and C.R. Raymond et., USGS OpenFile Report 2007-1047, Short Research Paper 010, 4 p.; doi:10.3133/of2007-1047.srp010.

\section{Introduction}

The Antarctic Peninsula is perhaps one of the most quickly warming regions of the world (Vaughan et al, 2003). The Holocene climate variability of this area is not fully understood, and the timing of deglaciation is not well known (Hjort et al, 1997). The recent withdrawal of the Larsen Ice Shelf system has increased the need to better understand the climate of the Antarctic Peninsula (Scambos et al, 2000). This work was conducted as part of a larger study to investigate environmental variability of the Antarctic Peninsula to determine if recent ice shelf retreat is unique or has previously occurred within the Holocene (Domack et al, 2003). Core NBP0003-JPC38, a sediment sequence recovered at a water depth of $760 \mathrm{~m}$ from the Vega Drift (Figure 1), Antarctica was analyzed for foraminifera to determine Holocene oceanographic and climatic variability of the region.

\section{Oceanography and modern foraminiferal distributions}

Water masses of the Antarctic Peninsula continental shelf are controlled by several factors including prevailing oceanographic boundaries, seaice, and glacial influence (Hofmann et al, 1996; and Gordon, 1998).

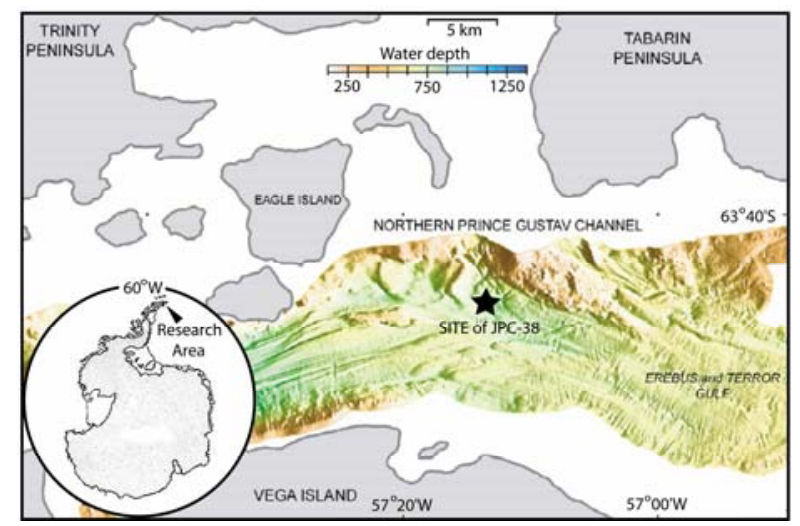

Figure 1. Map showing the location and bathymetry of JPC-38.

Two water masses, with distinct salinity and temperature characterize the shelf water of the Weddell Sea. The denser Hyper Saline Shelf Water (HSSW) is a product of sea-ice production on the shelf. The HSSW is characterized by salinities of $\sim 34.7 \mathrm{ppt}$ and temperatures of $\sim 1.9^{\circ} \mathrm{C}$. The lighter Ice Shelf Water (ISW) results from HSSW spreading below ice shelves, causing melting of glacial ice. This process results in lowered salinities of ISW ( $34.6 \mathrm{ppt})$. Temperatures of 
ISW range from 1.4 to $1.8^{\circ} \mathrm{C}$ (Gordon, 1998). These water masses affect the oceanography of the Bransfield Strait forming the Bransfield Strait water. The Bransfield Strait water is considered a mixture of Weddell Sea Shelf Water and the Upper Circumpolar Deep Water (Hofmann et al, 1996). The thermohaline characteristics of the Bransfield Strait water exhibit strong seasonal and interannual variability.

The distribution of foraminifera in the Antarctic is heavily dependent upon water mass characteristics (Anderson, 1975; Miliam and Anderson, 1985; Ishman and Domack, 1994). Corrosive bottom water, such as HSSW, impacts species composition and inhibits calcareous taxa from living or being preserved (Miliam and Anderson, 1985; Ishman and Szymcek, 2003). The presence of ISW allows for precipitation and preservation of calcareous foraminifera. ISW assemblages have been described in numerous studies (Anderson, 1975; Ishman and Szymcek, 2003). Foraminiferal communities associated with the Bransfield Strait water were documented by Ishman and Domack (1994), and similar communities were identified near the Larsen Channel, immediately to the north of the site of JPC-38 (Szymcek, 2005).

\section{Methods}

A total of 492 sediment samples, taken every $4 \mathrm{~cm}$, were collected from NBP0003-JPC-38. When abundances allowed, a total of 100 benthic foraminifera individuals were collected from the $\geq 63$ $\mu \mathrm{m}$ fraction of each sample. Planktic foraminifer species were collected when observed. In sediment samples where 100 foraminifera could not be collected all foraminifera from the sample were collected.

The core was analyzed using R-mode cluster analysis and Q-mode principal component analysis (PCA) in SPSS $^{\odot}$ to determine stratigraphic foraminiferal assemblage changes. Planktic foraminifera species were not analyzed in statistical routines, but were important in interpretations.

\section{Results}

A total of thirty-nine benthic and one planktic foraminiferal taxa were identified. Benthic taxa were used in statistical analyses of JPC-38. R-mode cluster analysis indicated three major groups of taxa interpreted as assemblages within JPC-38, the $S$. fusiformis, $T$. wiesneri, and, $M$. arenacea assemblages. The $S$. fusiformis assemblage is characterized by calcareous foraminiferal species including $S$. fusiformis, Globocassidulina biora, G. subglobosa, and Nonionella iridea. The $T$. wiesneri assemblage is characterized by agglutinated foraminiferal species such as T. wiesneri, Portatrochammina spp., Trochammina intermedia, and Spiroplectammina biformis. The $M$. arenacea assemblage is nearly a monospecific assemblage.
Q-mode principal component analysis of JPC-38 indicates that three factors comprise over $94 \%$ of variance in the core data (Figure 2). R-mode cluster analysis and Q-mode principle component analysis result in similar species associations. This analysis indicates that three factors best represent the largest percentage of variance in the core data. The principal components (PC) represent the stratigraphic distribution of $M$. arenacea (PC1), T. wiesneri (PC2), and S. fusiformis (PC3) assemblages. Respectively, these components explain $75.68 \%, 11.59 \%$, and $7.64 \%$ of the total variance of the principal components analysis.

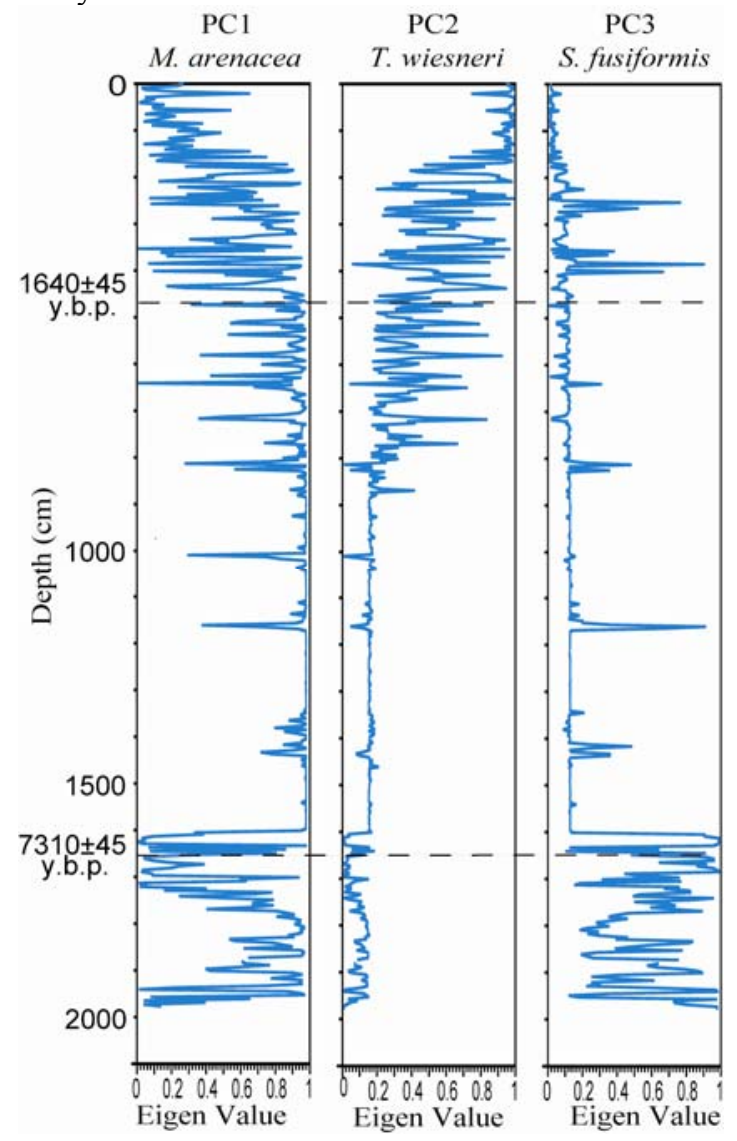

Figure 2. Distribution of the major foraminiferal Qmode principal components for JPC-38. PC1 represents $M$. arenacea, $\mathrm{PC} 2$ represents $T$. wiesneri, and PC3 represents $S$. fusiformis.

The upper $\sim 2.0 \mathrm{~m}$ of JPC-38 is represented by the $T$. wiesneri assemblage. The $T$. wiesneri assemblage accounts for $73.9 \%$ of this interval, while $M$. arenacea accounts for only $26.1 \%$. T. wiesneri is gradually removed, and at $\sim 9.0 \mathrm{~m}$ the assemblage becomes dominated by $M$. arenacea. $M$. arenacea increases in value down-core from $\sim 2.0$ to $\sim 9.0 \mathrm{~m}$ as the eigenvalue of the $T$. wiesneri assemblage decreases. Samples between $\sim 9.0 \mathrm{~m}$ and $\sim 16.00$ are dominated by the $M$. arenacea assemblage. The $T$. wiesneri assemblage makes up $7.4 \%$ of this interval, while $M$. arenacea 
accounts for $89.0 \%$. Some samples within this interval contain only $M$. arenacea. At $\sim 16.00 \mathrm{~m}$ the $S$. fusiformis assemblage becomes abundant. Calcareous species account for $53.6 \%$ of benthic foraminifers collected from this interval, while $M$. arenacea accounts for $44.7 \%$. M. arenacea is common, but other agglutinated species are uncommon. The calcareous species of this assemblage also occurs in several abrupt intervals within the upper 16 meters of the core. The planktic species Neogloboquadrina pachyderma cooccurs with the $S$. fusiformis assemblage. Foraminiferal distribution data and PCA results for JPC-38 can be found in Plate 1.

\section{Holocene foraminifera from the Vega Drift}

Three dominant benthic foraminifera species, $M$. arenacea, $T$. wiesneri, and $S$. fusiformis, represent more than $81 \%$ of the total number of tests recovered from JPC-38. The dominance of these species is shown in PCA results.

The species $M$. arenacea accounts for more than $64 \%$ of the total number of tests. In some samples, the species composition is limited to $M$. arenacea. The species $M$. arenacea is unique with respect to preservation potential. This species was found pervasively in samples collected from the Antarctic Peninsula (Szymcek, 2005) and it is common in surface samples associated with HSSW recovered in the nearby Prince Gustav Channel (Ishman and Szymcek, 2003). This species is also associated with the HSSW in the Weddell Sea by Anderson (1975). The preservation potential of $M$. arenacea is suggested to be independent of carbonate saturation and redox conditions (Schmeidl et al., 1997). The dominance of this species was also documented by Ishman and Sperling (2002) in ODP 1098b, collected from the Palmer Basin on the western margin of the Antarctic Peninsula. They suggested the dominance of $M$. arenacea to be due to its high preservation potential in cold corrosive bottom waters and reducing conditions.

The top 16.00 meters of the core is dominated by agglutinated forms, and characterized by high numbers of $M$. arenacea, $T$. wiesneri and subsidiary numbers of other agglutinated species. The unaltered assemblage of the modern Prince Gustav Channel is similar to the taxonomic characteristics of the upper $\sim 2.00 \mathrm{~m}$ of the core (Szymcek, 2005). Modern samples from the Prince Gustav Channel are dominated by T. weisneri, and $M$. arenacea. Other taxa found in surface samples and the upper $\sim 2.00$ meters of JPC-38 include Portatrochammina spp, Trochammina intermedia, and Spiroplectammina biformis. The T. wiesneri assemblage exhibits a decrease in abundance with increased depth between $\sim 2.00 \mathrm{~m}$ and $\sim 9.00 \mathrm{~m}$. Below $\sim 9.00 \mathrm{~m}$ the $T$. wiesneri assemblage is almost completely removed. The species $T$. wiesneri is commonly found in association with $M$. arenacea in modern sediments (Szymcek, 2005; Ishman and
Szymcek, 2003). The decrease in agglutinated tests may indicate post-depositional disintegration of agglutinated species except $M$. arenacea. Ishman and Sperling (2002) observed similar taphonomic alteration of agglutinated assemblages on the western Antarctic Peninsula margin.

Below $\sim 16.00 \mathrm{~m}$, core JPC-38 is characterized by abundant calcareous foraminifera of the $S$. fusiformis assemblage. This indicates the presence of noncorrosive bottom water, which may be similar to ISW or Bransfield Strait water. The S. fusiformis assemblage has greatest similarities to modern assemblages found in the high productivity fjords of the western Antarctic Peninsula (Szymcek, 2005; Ishman and Domack, 1994). Associations between $S$. fusiformis and productivity/low-oxygen conditions have been shown in other regions (Alve, 1995). Typically fjord assemblages are dominated by $S$. fusiformis, while other species are subsidiary. Ishman and Domack (1994) associated this taxon with abundant stable organic material in sediment and the presence of Bransfield Strait water.

Other important calcareous species found in the $S$. fusiformis assemblage include Globocassidulina biora, $G$. subglobosa, and $N$. iridea. These species are commonly associated with the presence of ISW (Anderson, 1975; Ishman and Szymcek, 2003). The planktic species $N$. pachyderma is also present. This species is common in areas influenced by the presence of ISW (Ishman and Szymcek, 2003).

\section{The Holocene oceanography and climatic record of the Vega Drift}

The benthic foraminiferal record of the Holocene Vega Drift indicates two major oceanographic and climatic intervals of Holocene. The record shows high relative productivity, which may be obscured in some intervals by carbonate dissolution. The early to midHolocene recorded a Vega Drift influenced by glaciation and the presence of ISW. The mid to late Holocene indicates a period strongly influenced by HSSW with sporadic intervals of glaciation.

\section{Early to mid-Holocene Vega Drift ( $<7000$ years before present)}

The early to mid-Holocene of the Vega Drift is characterized by input of glacial plume sediments composed of clayey silt (Camerlenghi et al, 2001), indicating increased glaciation of the Prince Gustav Channel during this interval. The glacial characteristics of this interval likely produced noncorrosive bottom waters, which may be similar to ISW and possibly Bransfield Strait water. The presence of $S$. fusiformis indicates environmental characteristics similar to the fjords of the western Antarctic Peninsula. A modern analog, where S. fusiformis is associated with glacial environments, is currently unknown. The authors suggest the early to mid-Holocene interval to 
be similar to environmental characteristics of the fjords of the western Antarctic Peninsula, but limited to an environmental regime capable of supporting glaciation. It is likely that this interval indicates increased productivity or low-oxygen conditions relative to other ISW foraminiferal communities at the site of JPC-38, allowing for the atypical occurrence of $S$. fusiformis.

\section{Mid to late Holocene Vega Drift ( >7000 years before present)}

This interval is similar to modern conditions in sedimentologic and foraminiferal characteristics. The mid to late Holocene is, in general, marked by depleted numbers of calcareous species. Calcareous foraminifers account for little more than $4 \%$ of the total number of tests recovered from this interval. This change indicates a shift in glacial conditions and production of HSSW at the Vega Drift site. During at least six intervals within the mid to late Holocene, conditions existed to allow the calcareous S. fusiformis assemblage to re-occur. These intervals indicate pulses of ISW to the Vega Drift. These events punctuated the production of HSSW at the Vega Drift.

Though limitations in dating prohibit identifying the exact timing of deglaciation, the event is loosely correlative to an Antarctic mid-Holocene warming event revealed in other studies (Hemer and Harris, 2003; Hodgson et al; 2004; Bentley et al, 2005; Pudsey et al, 2006).

\section{Summary}

Two major oceanographic and climatic intervals were interpreted based upon foraminiferal biostratigraphic sections within JPC-38. The early Holocene is dominated by the S. fusiformis assemblage, indicating glacial production of ISW marked by abundant calcareous foraminifera and the occurrence of planktic species. The mid to upper Holocene section of the core is dominated by the $M$. arenacea and $T$. wiesneri assemblages. The lack of $S$. fusiformis in this interval, and a shift from glacial sediments to drift sediments indicates deglaciation and warming in the mid-Holocene at $\sim 7000$ ybp. During at least six episodes within the mid to late Holocene, the $S$. fusiformis assemblage re-occurred, indicating pulses of ISW production and increased glaciation.

Interpretation of the foraminiferal record of the Vega Drift reveals Holocene oceanographic change. This record provides a better understanding of the Holocene environmental changes of the Vega Drift and Antarctic Peninsula.

\footnotetext{
Acknowledgements. We acknowledge the support from the U.S. National Science Foundation Office of Polar Programs through grants OPP-0338220, OPP-0338142 and OPP-0338163. We thank Captains and the crews of the research vessels and the staff of Raytheon Polar Services for their extraordinary effort during the cruises to collect these data. We acknowledge the support from the U.S. National Science Foundation Office of Polar Programs. We thank Jutta Wollenburg and an anonymous reviewer for their helpful
}

comments on this manuscript. We also thank our co-editor Dieter Futterer.

\section{References}

Alve, E. (1995), Benthic foraminiferal distribution and recolonization of formerly anoxic environments in Drammensfjord, Southern Norway, Marine Microplaeontol., 25, 169-186.

Anderson, J.B. (1975), Ecology and distribution of foraminifera in the Weddell Sea of Antarctica, Micropaleontol., 21, 69-96.

Bentley, M.J., D.A. Hodgson, D.E. Sugden, S.J. Roberts, J.A. Smith, M.J. Leng, C. Bryant (2005), Early Holocene retreat of the George VI Ice Shelf, Antarctic Peninsula, Geology, 33, 173-176.

Camerlenghi, A., E.W. Domack, M. Rebesco, R. Gilbert, S.E. Ishman, A. Leventer, S. Brachfeld, A. Drake (2001), Glacial morphology and post-glacial contourites in northern Prince Gustav Channel (NW Weddell Sea, Antarctica), Marine Geoph. Researchers, 22, 417-443.

Domack, E., A. Leventer, S. Root, J. Ring, E. Williams, D. Carlson, E. Hirshorn, W. Wright, R. Gilbert, G. Burr (2003), Marine sedimentary record of natural environmental variability and recent warming in the Antarctic Peninsula, Antarctic Res. Series, 79, 205-224.

Gordon, A.L. (1998), Western Weddell Sea thermohaline stratification, Antarctic Res. Series, 75, 215-240.

Hemer, M.A., P.T. Harris (2003), Sediment core from beneath the Amery Ice Shelf, East Antarctica, suggests mid-Holocene ice-shelf retreat, Geology, 31, 127-130.

Hjort, C., O. Ingolfsson, J.M. Lirio, and P. Moller (1997), Holocene glaciation and sea-level changes on James Ross Island, Antarctic Peninsula, J. Quaternary Science, 12, 259-273.

Hodgson, D.A., P.T Doran, D. Roberts, A. McMinn (2004), Paleolimnological studies from the Antarctic and sub Antarctic islands. In: Pienitz, R., Douglas, M.S.V., J.P. Smol, (Eds.), Developments in Palaeoenvironmental Research, 8. Long-term Environmental Change in Arctic and Antarctic Lakes. Kluwer, Dordrecht, pp. 419-474.

Hofmann, E.E., J.M. Klinck, C.M. Lascara, and D.A. Smith (1997), Water mass distribution and circulation of the Antarctic Peninsula and including Bransfield Strait, Antarctic Res. Series, 70, 61-80.

Ishman, S.E., and E.W. Domack (1994), Oceanographic controls on benthic foraminifers from the Bellingshausen margin of the Antarctic Peninsula, Marine Micropaleontol., 24, 119-155.

Ishman, S.E., and M.R. Sperling (2002), Benthic foraminiferal record of Holocene deep-water evolution in the Palmer Deep, western Antarctic Peninsula, Geology, 30, 435-438.

Ishman, S.E., and P. Szymcek (2003), The impact of ice shelf decay on the spatial and temporal distributions of foraminifera: Larsen-A Ice Shelf and the Prince Gustav Channel, eastern Antarctic Peninsula, Antarctic Res. Series, 79, 239-260.

Scambos, T.A., C. Hulbe, M. Fahnestock, J. Bohlander (2000), The link between climate warming and break-up of ice shelves in the Antarctic Peninsula, J. of Glaciology 46, 516-530.

Schmiedl, G., A. Mackensen., P.J. Mueller (1997), Recent foraminifera from the eastern South Atlantic Ocean: Dependence on food supply and water masses, Marine Micropaleontol., 32, 249-287.

Szymcek, P. (2005), Modern Foraminifera of the Antarctic Peninsula, Masters Thesis, 163 pp., Southern Illinois University at Carbondale, Carbondale, IL.

Vaughan, D.G., G.J. Marshall, W.M. Connolley, C. Parkinson, R. Mulvaney, D.A. Hodgson, J.C. King, C.J. Pudsey, J. Turner (2003), Recent rapid regional warming on the Antarctic Peninsula, Climatic Change, 60, 243-274. 